\section{Features of a Grassland Theory ${ }^{1}$}

\section{ERNST KLAPP}

Honorable Doctor of Agriculture, Professor of Agronomy, formerly Director of the Institut für Pflanzenbau, University Bonn, Germany.

\section{Highlight}

The leading grassland authority in Germany outlines his views on grass associations and competitive ability of individual species as influenced by management.

In Germany the exploration of grassland in a true sense, i.e., the behavior of a permanent grass sward as a plant community, has developed slowly and only recently. After intense stimulation from botanists (Stebler and Schröter 1887 a,b,c; 1892; 1898; Weber and Emmerling, 1917) "it is to find a remarkable silence (in agricultural literature) about grassland after 1900" (Baur, 1930). Up to the time of the first world war questions of the single plant, its biology and breeding, seed production, and forage value were in the fore- ground. They dominated the textbooks and teaching with long discussions about culturetechnics, seed mixtures and harvesting methods. Fertilization and cropping procedures were also discussed. At this point, grassland theory withdraws from the facts and the causes of improper methods in research and teaching become evident. In the scientific view, the historical orientation toward arable farming doubtless makes difficult the comprehension of the special character of grassland.

\section{Crop Farming and Grassland Theory}

The scope of the cropping system is relatively solid with classical parts on soil preparation, fertilization, seeds and cultivation. The special system of in- struction for plant production stands next to it in traditional form. The theories of cropping and plant production on cultivated soils represent a coherent frame upon which it is possible to assimilate new systems without difficulty.

Such a solid base was long lacking for the grassland plant community. The special theory of plant production of grassland plants in single crop cultures was indeed far developed but it was

1 This article was published in Wissenschaftliche Zeitschrift der Universität Jena 7:67-81.1957/58. It was translated by Privatdozent $D r$. D. F. R. Bommer, Institut für Grünlandwirtschaft und Futterbau, University Giessen, Germany, as a contribution to the discussions held during 1962 with many scientists and research workers in U.S.A. The translator is greatly indebted for careful reading and linguistic improvements in the manuscript to $M r$. E. J. Woolfolk, formerly Editor, Journal of Range Management, and presently Project Manager, Centro de Investigaciones Agricolas Alberto Boerger, La Estanzuela, Colonia, Uruguay. 
used on arable soils with methods of cropping and not under the conditions of the dense grass sward composed of many species. So it was new ground on which the younger grassland research had to develop new ways from very different viewpoints. This process had to lead sooner or later to a synthesis, to a realization of the basic facts, i.e., to a general and a special grassland theory. The subject of the first would be the rules generally followed by the grass sward under the influences of the environment, including man and his stock. The subject of the latter would be the behavior of the single plant species in the community. Both are necessary not only for the biology and the technics of treatment of the grass sward but for viewpoints on economy, harvesting methods, and forage value. While the soil and its treatment and the treatment of the single plant species (or of most simple, short-lived mixtures) are the raw material and tools of cropping, the treatment of a "permanent community" is the scope of grassland management and must be largely without cultivation.

\section{Character of the Grassland}

With very few exceptions the grassland, like the cropland, is not "natural". It developed only by the effects of man and his animals. The original vegetation, mostly forest but also moor and reed banks, fell back against the ax, fire, mowing, and grazing. And only regular mowing and grazing sufficiently used will keep the original vegetation from coming back (Davies, 1948; Klapp, 1954). With decreasing intensity of utilization, reinvasion by the most adapted vegetation will take place. From the phytosociological viewpoint the agriculturally used grass sward is a "replacing community" (Braun-Blanquet, 1951; Ellenberg, 1956). It replaces another community which would be present without agricultural use of the area. Its composition is unstable particularly in its dependence on the intensity of utilization. So, the grass sward is more closely related to the original vegetation than to the cropland (Davies, 1948). It is separated from the latter particularly by the continuous resting of the soil with all the following effects, but alsonot less important for the management-by the fact of the plant community, the species mixture.

\section{Density}

The more or less complete density of the grass sward largely excludes danger of erosion. Its effect on the soil climate slows down decomposition of the organic material in spite of the high biological activity (Franz, 1950; Wehsarg, 1935). Both make possible a permanent friable state with highly valuable contributions to soil structure (Morgenweck, 1941/42).

For a long time the small possibility of using mechanical cultivation on the grassland was called a weak point. But as a rule the main purpose of tillage, soil loosening, is unimportant under a grass sward. Here, loosening and building of soil structure are better done by the plant cover and soil fauna than by mechanical treatments. Repeated and deep mechanical treatment of the grassland soil leads to conditions of arable soils, i.e., to increased decomposition of the organic material and to weakness of the soil structure (Klapp, 1942/43; Klitsch, 1932/33; Morgenweck, 1941/42; Schünemann, 1933). Likewise the opinion that working and mixing fertilizer into the soil is necessary to obtain adequate utilization of the fertilizer nutrients must be supposed as disproved (Klapp, 1944). Even surface application of fertilizer nutrients are utilized by the grass sward just as well or often better than by arable crops (Klapp, 1954). Principally the nutrient supply of the plant need not pass through the soil. The nutrient turnover in a tropical jungle takes place to a large extent in the succession of leaf-leaf droppingroots-leaf and makes possible a luxurious growth even on very poor soils. This is true also in the grass sward, where a sufficient nutrient supply may produce high yields even without noticeable enrichment of the soil. In this respect the large concentration of roots in a thin surface layer plays an important role (Klapp, 1958).

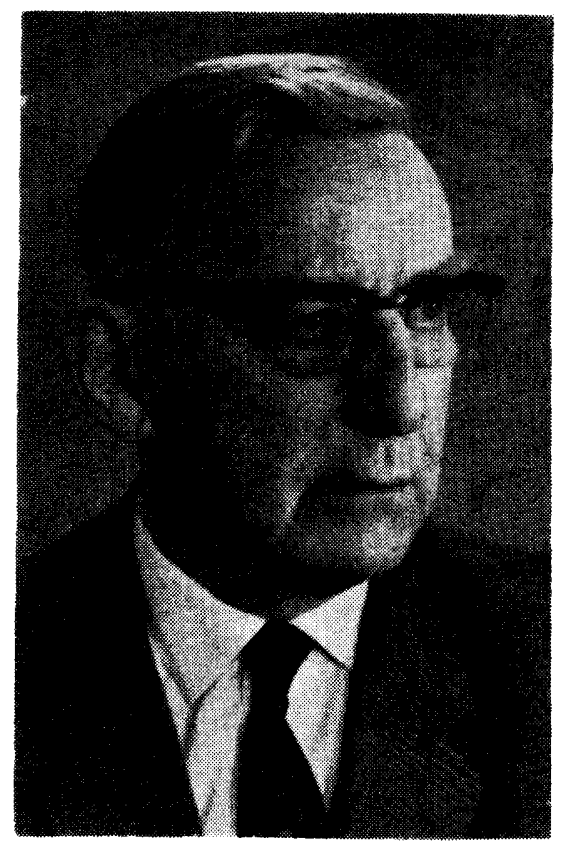

Dr. Ernst Klapp studied Agricultural Science at Gottingen and Munchen. After his Doctor thesis in 1923 at Munchen and especially as Director of the Institut fur Acker-und Pflanzenbau, University Jena and later of the Institut fur Pflanzenbau, University Bonn, he was engaged in the development of modern Grassland Science. $\mathrm{He}$ is still the leading scientist in this field in Germany. In addition to other publications his books "Wiesen und Weiden" (2nd Ed. 1954) and "Lehrbuch des Acker-und Pflanzenbaus" (5th Ed. 1958) are well known.

\section{Perenniality}

The perenniality of the grass sward by no means implies invariability. True survival for decades of the same plant on the same place occurs relatively seldom. There is a constant growing and passing away, a change in place especially conspicuous in species with stolons and rhizomes. It also occurs in bunch types. With self-incompatible species (legumes) this change in place supplants the temporal crop rotation in arable fields (Brünner, 1956; Klapp, 1954). It also makes possible the covering of bare spaces after dyingoff of some or all individuals of one species (e.g. short-lived plants) and after decreases of some species by weather extremes, flooding and management mistakes.

Otherwise the development and life of the species, determined in the botanical garden or the experimental field, or in other words in a single plant crop, does not prevail 
in the dense grass sward. Thus, as Linkola (1935) has shown, the minimum juvenile phase alone (until the first flowering) is often 3 to 8 or more years in different species. The slow juvenile development of grassland plants is very important. It may be accelerated very much by improving growing conditions. The presence of numerous individuals in an early vegetative stage represents a yield reserve and is likewise a base for great possibilities of grassland improvement by fertilization.

The maintenance of a grassland sward through many decades or even centuries may be enigmatical with the limited perenniality of grassland plants, particularly when seed production is lacking and reproduction by stolons or rhizomes is unimportant. This may be the case for instance with intensively used ryegrass (Lolium) pastures and lawns. But there are many possibilities of self rejuvenation. In many grasses known as pure bunchgrasses, stolons have been observed, also tillers pulled off by grazing animals or machines may be able to root under favorable conditions (De Vries, 1943; Weber, 1929). The seed source in grassland soils is generally large (Champness and Morris, 1948; Foerster, 1956). Even though possibilities of germination may be low and mortality of seedlings very high, every disturbance of the sward and every covering with soil carries opportunities for development. In addition the seed source of the grassland soil is supplemented by seeds carried in by grazing animals, by farmyard manure, wind, floods, and so on (Foerster, 1956; Lennartz, 1957). Where there is neither a seed source of long-lived grassland plants nor the opportunity to spread seeds by animals, we do not find a typical grass sward even under suitable environmental conditions. In the cool temperate regions of Chile where originally a native grassland flora is lacking, the development of a perennial grass sward in our sense is possible only after a base of seed distribution has been established by the introduction of suitable European forage plants. Only then are typical "European" grass swards developed (Klapp, 1956).

On the other hand, long summer drought periods in some countries prevent the growth of a grassland flora typical of cool temperate regions. The permanent grassland in such cases has quite another character. It is often composed of summer or winter annuals which reproduce by seeds. This may require protection from grazing during some time of the year up to seed shattering and is one of the reasons for deferred grazing of such grasslands. In some countries a similar system was introduced in the shifting use of the arable land, e.g. the careful management of crimson clover, (Trifolium incarnatum), allowing sufficient annual seed maturation and shattering for reproduction (Klapp, 1956). With the dominance of perennial species similar to long-lived arable crops like alfalfa, the grass sward requires exploitation for maintenance of growth. Effects are followed by after-effects. No management procedure is without such an after-effect in the regrowth of the same or the following year. Light and heavy use, starvation and plentiful fertilization are expressed for a long time in the behavior of the grass sward.

\section{Plasticity}

The mixture of numerous plant species in the grass sward is its third and perhaps most substantial characteristic. Its advantage is not only that of other mixed crops such as better exploitation of the soil and environmental conditions, more security, many-sided forage value and so on. But the species association together with the perenniality causes above all the plasticity of the sward (Klapp, 1954). A crop field of potatoes or of wheat keeps its character as such with orderly management, whether fertilized light or heavy, with or without nitrogen and in wet or dry years. A pure stand of Italian ryegrass (Lolium multiflorum) remains such, even though grazed, cut early for silage, or cut late for hay. The grass sward on the other hand changes its composition at least in relation to the quantity of the species, with every change in fertilization, in kind of utilization, with fluctuation of the ground water level and annual weather conditions. This plasticity of the sward, its tendency to develop an equilibrium with the environment, is the most important fundamental of all grassland management. Depending on the treatment, it is possible to develop from an original uniform sward bloomrich meadows, pure green pastures, good and poor stands, swards of trample plant communities and bush communities. This means it is possible to direct the composition of the grass sward, theoretically and in most cases practically too, in any desired direction. At any rate the presence of a multinumber of different species is the supposition of this plasticity. There are on one side tall grass meadows very poor in species number, on the other side intensive pastures with very few species. Both types at least for some time are less changeable, but they are exceptions. As a rule the sward is composed of several or many species, grasses, legumes and other herbs, with different requirements. (This division in three parts has been criticized as unnatural, but it is justified in the view of grassland management. With all the differences within these three groups each is rather well characterized by its specific behavior under fertilization and exploitation, by peculiarities of harvesting and forage value.)

First, the plasticity of the grass sward is surprising. We would assume that species in the same location would generally have the same growth requirements. But there are no two species which finally correspond in their requirements; they are only similar. The similarity of the requirements, too, is valid only for a specific combination of the environmental factors. When this is changed the species equilibrium of the plant community will be shifted together with the effect of the environmental factors. There is no soil change, no kind of fertilization and exploitation, no change of annual weather conditions or of water supply, which will affect all species of the grass sward in the same way. Promotion of one species means retardation of others. Generally these relationships become more pronounced with the increasing intensity of management. The community becomes poorer in species composition the more effective and onesided the treatment, e.g. heavy nitrogen application or controlled grazing with high pressure.

Density, perenniality and plasticity are those characteristics of the grass sward which prohibit the use of many, even most practices used on 
arable crops. As the fundamentals of grassland management these characteristics ask for the development of a general and specific grassland theory, a theory less about the individuality of the single species but much more about the behavior of a plant community.

\section{Species-Specific Behavior of Grassland Plants}

In order to learn accurately the behavior of the single species, which is very important for the change of the grass sward, it would be necessary strictly speaking to study it in the formation of the grass sward (Caputa, 1948; Ellenberg, 1956; Knapp, 1955; Remy and Vasters, 1931; Vohl, 1935). At first, we should study the behavior of the species in mixed stands of uniform composition under the effect of different factors and different habitats. But it is very difficult to make experiments of that kind. Every specialist knows how difficult it is even to develop new seedings to homogeneous stands. Experiments with mixtures even of few species and only a few problems necessitate an unusual expenditure of work for the botanical analysis.

The solution of the simple problem, how does speices $A$ behave in a five-species mixture, under cutting, under grazing and under cutting and grazing combined with different fertilization, keeps one person busy during several vegetation periods. The countless possibilities of sites and species composition do not allow thorough studies even of the most important problems. It is typical that the testing of the forage plant varieties generally even today renounce the testing of pasture plants under grazing in mixtures.

Field experiments may include the whole range of species combinations and environmental conditions. But rarely are two cases strictly comparable in all qualities outside the factor to be tested. Yet we owe to plant ecology and phytosociology as the inductive methods, many important viewpoints in the behavior of species (Ellenberg, 1952; 1956; Klapp, 1949; Schmithüsen, 1942; Tüxen, 1939).

In addition we turn to the study of single species in pure cultures or even in single plantings to observe fundamental tendencies in their behavior. One must be aware of the sources of error in such tests. One should do the simple experiment of giving different grasses increasing amounts of nitrogen in pure stands on the one hand and in mixtures on the other. In the first case all species will show a very similar percentage growth increase; in the second, some species will be especially promoted, others nearly suppressed. The different behavior of the species in pure stands may be explained by the lack of competition or perhaps by the lack of protection given by the dense sward. Furthermore, it may be recalled that the development and life duration of the species in a dense sward differs widely from a field experiment (Linkola, 1935). Tillering, creeping and heading show a different picture in the field experiment than in the grass sward. Also in many cases the species in the sward suffer less from extremes of utilization and weather than in pure field stands or single plantings.

\section{Life Duration}

Summer and winter annuals are undesirable especially in meadows because most of them produce ripe seed before or during the time of hay curing. Then their forage value is reduced to that of straw and they may moreover behave like weeds. But they are by no means always worthless. They colonize at least temporarily the open spaces caused by frost, water and overuse. Annual bluegrass (Poa annua) in pastures, racemose chess (Bromus racemosus) and even soft chess (Bromus mollis) are examples. A large occurrence of short-lived species is mostly caused by an insufficient density of the sward in our climate.

Long-lived species support the continuity of the grassland productivity. The consideration necessary for the maintenance of the vitality mentioned before applies fully to them.

\section{Storage and Exhaustion}

The precondition for maintenance of vitality-the ability of regrowthfrom one year to another, even from one time of utilization to anotheris the accumulation of reserve storage material (Klapp, 1941/42; 1958; Klapp and Schulze, 1957; Smelow, 1937). In this respect the species show large differences in the start and the time needed for storage. Moor grass (Molinia caerulea) must have undisturbed assimilation and storage up to late fall if development the following year is to be normal. The application of two cuts is the main reason that this once widely distributed grass has practically disappeared from better meadows. Conversely it forms vigorous stands in the litter-meadows of the alps forelands, if cut only once during straw ripening in September-October.

On the contrary, perennial ryegrass (Lolium perenne) stores adequate food rescrves even under very frequent grazing and an intensive system of lawn cutting. Flowering and seed ripening with infrequent utilization are important for survival of moor grass but are rather detrimental for the longevity of perennial ryegrass.

Most other grassland plants are between these two extremes. After effects of frequent cutting systems for two years in an experiment with large pots are shown in Table 1 (Klapp, 1941/42; Klapp and Schulze, 1957).

White clover cut each time in the "ready-for-grazing stage" withstood best multiple exploitation. Birdsfoot trefoil was eliminated under the same system. The rank of the grasses corresponds about to the resistance against grazing and cutting observed in practice.

The causes of the differences in sensitivity to frequency of utilization of grassland plants are not completely known. The different growth habits, especially spatial distribution of assimilation organs, are a useful work hypothesis (Klapp, 1941/42; 1958). Vigorously tillering grasses always keep a considerable leaf area for assimilation even under frequent utilization. In comparison grasses with few basal leaves or leaves on long culm-tillers (tall grasses, e.g., reed canary grass, tall oat grass) lose almost their whole leaf area with every cut. Grasses of the first kind are able to store almost without interruption. Those of the second kind need long rest periods as in a two- to three-cut system to store sufficiently.

White clover is especially favored because its stolons are also able to assimilate and are practically never removed by utilization. On the contrary all climbing legumes such as vetches (Vicia, Lathyrus) leave only remnants of the culms and are especially sensitive to exploitation. Comparable differences are found 
Table 1. Relative yields with 6 to 13 cuts over two years. 1

\begin{tabular}{lccc}
\hline Species & Leaves & Stubble & Roots \\
\hline $\begin{array}{l}\text { White clover, } \\
\text { (Trifolium repens) }\end{array}$ & 51.9 & 72.2 & 27.7 \\
$\begin{array}{l}\text { Red fescue, } \\
\text { (Festuca rubra) }\end{array}$ & 24.8 & 51.2 & 31.8 \\
$\begin{array}{l}\text { Perennial ryegrass, } \\
\text { (Lolium perenne) }\end{array}$ & 22.5 & 26.7 & 24.9 \\
$\begin{array}{l}\text { Kentucky bluegrass, } \\
\text { (Poa pratensis) }\end{array}$ & 34.8 & 17.7 & 14.9 \\
$\begin{array}{l}\text { Reed canary grass, } \\
\text { (Phalaris arundinacea) }\end{array}$ & 19.4 & 7.2 & 10.4 \\
$\begin{array}{l}\text { Tall oat grass, } \\
\text { (Arrhenatherum elatius) }\end{array}$ & 9.2 & 4.9 & 3.6 \\
$\begin{array}{l}\text { Birdsfoot trefoil, } \\
\text { (Lotus corniculatus) }\end{array}$ & annihilated & & \\
\hline
\end{tabular}

1 Yield from system with infrequent 2 to 4 cuts $=100$.

among the majority of the other herbs. High bush-like forms are sensitive while rosette forms are resistant to utilization. Rosette leaves, being close to the soil surface, escape the scythe or the bite of the grazing animal.

It is evident in Table 1 that frequent utilization reduces the amount of underground organs more than the production of leaves. This is also the rule and the source of important peculiarities of heavy used grass swards. Rhizomes behave similarly. Although they have to be considered in many cases as storage organs they are not important for the resistance of the species against utilization. Grasses with such huge rhizomes as reed (Phragmites) and reed canary grass are very sensitive to grazing. Wehsarg (1935) gives obvious explanations for the inferiority of species with deep growing rhizomes in the grassland. Kentucky bluegrass and red fescue are no exceptions. Their rhizomes are very shallow. Both species prefer loose soils and on heavy soils are inferior to noncreeping perennial ryegrass under continuous trampling.

One example, calculated from more than 2000 vegetation studies, may give a picture of the behavior of some species under different systems of utilization in the field as shown in Table 2 (Klapp, 1954).

Meadow foxtail, vetchling and hawk's-beard are meadow plants very sensitive to grazing. Perennial ryegrass and plantain are highly resistant and yarrow seems to be indifferent.

Duration of the productive growth period is of some importance. Peren-
Table 2. Behavior of species in permanent pasture under different systems of utilization; occurrence in meadows equals 100 .

\begin{tabular}{|c|c|c|}
\hline Species & $\begin{array}{c}\text { Steadi- } \\
\text { ness }\end{array}$ & Amt. \\
\hline Tall oat grass & 20 & 5 \\
\hline \multicolumn{3}{|l|}{ Meadow foxtail } \\
\hline (Alopecurus pratensis) & 39 & 37 \\
\hline Kentucky bluegrass & 122 & 268 \\
\hline Perennial ryegrass & 291 & 2440 \\
\hline \multicolumn{3}{|l|}{ Yellow vetchling } \\
\hline (Lathyrus pratensis) & 22 & 3 \\
\hline White clover & 119 & 540 \\
\hline \multicolumn{3}{|l|}{ Biennial hawk's-beard } \\
\hline (Crepis biennis) & 10 & 2 \\
\hline Common yarrow & & \\
\hline (Achillea millefolium) & 96 & 92 \\
\hline \multicolumn{3}{|l|}{ Common plantain } \\
\hline (Plantago major) & 1200 & 2300 \\
\hline
\end{tabular}

nial ryegrass and rough-stalked meadow grass (Poa trivialis) have the ability to produce new tillers in the fall and thus provide abundant fall grazing especially in the zone of ocean climate. Kentucky bluegrass and red fescue on the other hand cease growth relatively early especially at some distance from the ocean. Among the hay grasses, those species equipped for repeated tiller elongation during the year are of special importance for regrowth. Finally in the sea climate area the presence of winter-green species is of advantage not only for spring growth of pasture but also for the possibility of winter grazing - the English "Foggage System" (Davies, 1948a; Hughes, 1953).

For the numerous other characteristics of grassland species only the principal differences of nutrient uptake and accordingly of nutrient content may be emphasized here. Grasses are relatively poor in protein and minerals except for potassium but high in crude fiber as compared to legumes which have double the amount of protein, calcium, and magnesium in comparable stages of development. Other herbs in total show the highest mineral contents and are always richer in protein than the grasses and have high contents of trace elements (Ahrens, 1957; Bender, 1940; Klapp, $1954)$. Even with this rough evaluation the considerable differences within groups of species can not be overlooked.

Nutrient content does not mean the same as palatability and it may not be especially wholesome. Some known or suspected poisonous plants are marked by high nutrient content. The preference of animals for the different species is not certain in-so-far as they are actually eaten as forage. Regardless, the palatability differences of grazed and avoided plants are of principal importance for pasture and range management. To be avoided by the grazing animal is synonymous with being saved. Thorny, prickly, sharpedged, pungent and therefore avoided species force the grassland farmer to many tricks to create and keep an even and high-grade grass sward.

\section{The Species Association and Shifts of Its Balance; Selective Effects}

Let us return from the behavior of the single species to the species association of the grass sward. It is not always an association unit in the sense of phytosociology and still less often an "association individual" (Braun-Blanquet, 1951; Ellenberg, 1956; Klapp, 1949). Younger seedings have not yet reached the stage of equilibrium with their environment. They contain many accidental components. Stands supposed to be similar are those which have been badly injured or whose environment has been substantially changed, for instance by water regulation. But also in older stands, well characterized association individuals are almost exceptions. Transitions and mixtures are the rule. This corresponds to the many-sided character and the often rapid spatial change of environmental conditions. A variety of species combinations from the sea 
coast to the mountains is hidden by temporary green color, their only common character. Often in a few meters distance the extremes will have not even one species in common.

Given a certain constant management, the mosaic of species combinations in a single case is nevertheless in a certain balance with environment. But this balance is unstable, at least for the proportions of the associated species. This limitation on proportion is important since quantitative changes do not qualitatively impair the characteristic species combination of a special location. This means, even economically, that considerable changes in the mass proportions leave the orginal plant community recognizable for the phytosociologist. Principal changes of the environment, e.g., lowering of the ground water table or uncommon changes in the management, e.g. multiple utilization with high fertilization, are necessary to eliminate the last characteristics of the original plant community.

Smaller differences which scarcely influence the species combination occur with extreme annual weather conditions (De Vries, 1940, 1942). A dry summer followed by a cold winter favors species with inclination to continental conditions and pushes back species of the more maritime region. This is especially evident with perennial ryegrass after winter damage. Even the layman will recognize the annual fluctuation in the proportion of the conspicuously flowering common buttercup (Ranunculus acer) and ragged-Robin (Lynchnis flos cuculi) in the changing color mosaic of a meadow. Moist years followed by mild winters and wet, cold springs bring these and other moisture preferring species to visible predominance.

Temporary high ground water tables, floodings, and particularly standing water have conspicuous effects-sometimes for many years -on the mass proportion of species (Krause, 1953; Schwarz, 1933; Stebler and Schröder, 1887 a). The effects of environmental factors upon a population in the sense of plant breeding, i.e. selection (Klapp, 1954), are obvious when there is a great depression or even a temporary loss of some species, an increase or invasion of others. The plasticity of the grass sward is based only to a small extent upon wide "ecological adaptability" of the single species, but to a larger extent upon the selective effects of the environmental influence. The more effective the selective factor the farther the selection encroaches from quantitative to qualitative changes in the grass sward, from changes in the mass proportion to those of species combination.

The most effective selection comes from man and his stock. Its direction and control are the cardinal points of grassland management ( $v$. Bothmer, 1953; Fenton, 1951/52; Jones and Jones, 1930; Klapp, 1954; Könekamp and König, 1929).

\section{Fertilization}

The selective effects of grassland fertilization, particularly meadow fertilization, are the most simple and today the best known (Klapp, 1931; 1954; König, 1950; Stebler and Schröter, $1887 \mathrm{c}$ ). The species of a grassland plant community which are in equilibrium with their environment seem to have similar requirements. It would be better to say that the species of the grass sward are satisfied with similar requirements in their balanced environment under conditions of mutual competition. These environmental conditions may moreover be below the physiological optimum of the species. (More information about the differences of the physiological optimum in pure stands and the ecological behavior in the plant community is given by Ellenberg (1956)).

Species with high fertility requirements often are found in unfertilized meadows. Their fertilizer requirement for high production is not met and their growth is poor, the more so since they have to compete with less ambitious species above and below the soil surface. Otherwise these are able to grow well not only on account of their excellent ability to utilize the soil nutrients, but also because the competition pressure of ambitious species is low.

But there is no kind of fertilizer with single nutrients or nutrient combinations equally useful for all species of the plant community. Each species is an individual in respect to nutrient requirement, adaptability and utilization. Application of fertilizer to a previously unfertilized meadow will break up the existing balance in the grass sward for the benefit of species "ambitious" for fertilizer. This "gratitude for fertilizer" consists not only in a particularly high fertilizer requirement but often also in the ability to take up more easily the nutrients lacking in the applied fertilizer.

Meadow fertilization with potassium and phosphate favors particularly the legumes, because this group is not able to take up enough of these nutrients in poor soils or under strong competition. Otherwise they are better able to collect the nitrogen "lacking" in the potassiumphosphate fertilizer the more abundant the supply with $\mathrm{P}_{2} \mathrm{O}_{5}$ and $\mathrm{K}_{2} \mathrm{O}$. If some species of the parsley family (Umbelliferae) overgrow all others with strong one-sided application of nitrogen and potassium in liquid manure, it is obvious that they are able to take up the soil phosphate better than other species.

Every time any kind of fertilization favors some single species or species groups whose competing ability is increased, other species or species groups are depressed. It is a question of the intensity and duration of the fertilizer effect. In the extreme it may come to the development of swards with very few species because every fertilization diminishes the number of species.

The depression of species by fertilization does not need to be actually harmful. Physiological damage by fertilization occurs very seldom, disregarding mistakes of application, e.g. by a heavy shift in the reaction of soils poor in bases following heavy fertilization over many years with acid fertilizers. As a rule the receding species are only indirectly affected, i.e. ecologically by the increased competition for light and nutrients. Nitrogen application is not generally detrimental to the legumes. This is known from crop farming. Here, in pure cultures with competition eliminated, peas, beans, and even clover species well repay a nitrogen fertilization. If there is competition in a crop field, for instance in a grass-clover mixture, heavy nitrogen rates are unfavorable to the clover because of increased competition from the grasses. 
Consequently fertilization as a selection factor has a partly positive and a partly negative effect upon the members of a plant community without direct physiological damage to the decreasing species. This fact opens some possibilities of changing species composition, for instance the proportion of clover and grass. Otherwise we may conclude that undesirable changes of the balance can be prevented or restricted by counteracting the vigor of competition by grazing or cutting of the species favored by fertilization.

The example of fertilization shows an effect of fertilizers not applicable to pure cultures of the crop field. Fertilization of pure stands influences directly the yield and the composition of the plant. In a plant community a third indirect effect is added, i.e. the alteration of the chemical composition of grassland yield with the alteration of the proportion of the species. The content of protein and minerals in the crop rises more with the increase of the clover proportion than by the direct increase of the content in the single species (Klapp, 1954).

\section{Selective Effects of Utilization}

The selective effects of utilization are less universally known than those of fertilization, although they are more effective and more important economically. It may be recalled that meadows and pastures owe their origin only to selection by scythe and grazing during which predominantly woody plants are the victims. (The presence of dwarf shrub heaths seems to point to the contrary).

The bases of selection by the kind of utilization are the species differences in rhythm of storage and exhaustion of reserve material, of defoliation and regeneration. Certainly the assumption of the selective influence on a species is that it is actually affected by the utilization. The difference between the effects of mowing and grazing becomes immediately clear with the comparison of a two-cut meadow and a pasture at the same location. The meadow has more species, more high bushes and is poorer in low growing grasses and legumes, its sward is less dense than that of a pasture.

\section{Mowing Effects}

Cutting a meadow twice allows undisturbed growth during two and more months between cuts and favors species with very different kinds of development. Mostly these are the undesirable early-flowering species, chiefly annuals and biennials, dependent on seed propagation. But predominantly those species which are able to store sufficient reserve material for regrowth or overwintering derive benefit from the two-cut system. This is true for tall grasses like tall oat grass and meadow foxtail, for all climbing or tall growing legumes, as well for numerous large bushes of the Compositae, Umbelliferae and Rosaceae.

Some short grasses, particularly perennial ryegrass, the low growing white clover, and many other low growing species are handicapped. Therefore the sward of a vigorous two-cut meadow is mostly very scattered and offers good possibilities for seedling establishment. In total, the picture of a blossomrich average meadow is a true expression of selection by a two-cut system, i.e., a mild kind of utilization.

In view of the decisive importance of uninterrupted storage of reserve material it seems that a one-cut system would be particularly advantageous for the desirable meadow plants. But this is not the case. One late cut favors quite another category of meadow plants than a two-cut system, namely species which need a particularly long time for reserve storage or seed ripening. These species, with very few exceptions, are without forage value. This may be generally on account of their late harvest. Some of them are especially valuable as litter, particularly moor grass. This grass reaches almost a man's height without fertilization and with late cuts; together with other similar reacting species, it produces remarkable yields and displaces the typical twocut plants. (For details of the selection by late cuts of the litter meadows refer to Stebler and Volkart, 1898).

The selection runs still differently with an increase in number of cuts. This is frequently recommended for improvement in forage value, but as a rule has been without convincing demonstration. A large number of the best forage plants common in two-cut meadows is repressed or even displaced under a regular three-cut system. This is true of tall oat grass and other tall grasses as well as the climbing legumes. Their place is occupied not only by short grasses but also by light-wanting and cut-resistant herbs, particularly those with rosette growth. The length of the rest periods between cuts is insufficient under average conditions for storage of reserve material by the typical two-cut plants. the result is mostly a lasting depression in yield (Schulze, 1954).

The moisture-preferring grasses of the stream valleys forming extremcly vigorous stands, call for the three-cut not only because of the forage value but also because of their resistance to it. This is true for reed canary grass and showy manna-grass (Glyceria maxima). Their quick growth greatly restricts competition of other species.

As a rule the locally used cutting system is based on experience. Generally it may not be wise to recommend a change, especially to increase the cutting sequence, except for a substantial increase of vigor (better supply of water and nutrients). In such case the effects described above for the three-cut may occur only with a four-cut system. Even then selective effects of many cuts, but a large reduction in yield, can not be avoided with optimum fertilization. The relatively frequent cut greenfeeding meadows of the high rainfall areas are usually very poor in grasses and dominated by tall herbs. The productivity of these meadows is maintained by high applications of liquid and semi-liquid manure. The attempt to exercise a frequent cut system without sufficient supplies of water and nutrients will lead without exception to the disappearance of the best forage plants.

It might appear surprising that maintenance of dense lawns preponderantly composed of grasses is possible in spite of quick succeeding cuts or even that grasses may grow here which otherwise would be destroyed by three to five cuttings. To understand this, let us compare the condition of the sward of tall grown grasses with that of a lawn after cutting. In the first case, there remains only pale stubble without leaves or ability to assimilate. Therefore the plants must develop new functioning leaf blades. In the lawn the stubble is normally green and ready to assimilate immediately. The lawn is so short that enough light 
always reaches the lowest leaves and culm portions for chlorophyll production. Here one important factor of the competition, shading, is eliminated. The very intensive tillering facilitates, so to speak, the "adaptability" of the growth form to the close cut, by which a large portion of the assimilating leaf area escapes. The development of leaves close to the ground is further favored by rolling after every cut.

But if regular water and nutrient supply (at least by a fertile soil) are lacking, the lawn effect fails to develop and a special and heavy selection starts. Plants are selected which are only incompletely cut or which in spite of the frequent cuts, are able to set seed, common and hoary plantain, common dandelion (Taraxacum officinale), English daisy (Bellis perennis) and others. So, even in the classical lawn country, England, we often find a plantain pavement instead of a lawn.

The selection effects of various cutting frequencies on the aerial plant parts show a parallel in the subterranean plant development (Klapp, 1958; Troughton, 1957). With few exceptions there are interactions between plant height and root depth, between the total aerial production and the amount of roots. The tall grasses sensitive to frequent cutting, root deeper than the less sensitive short grasses. The graduation of the root depth becomes shallower when the tall grasses are displaced by frequent cutting. The analogy is also true for less deeply rooted and more cut-resistant species. With increasing cutting frequency the concentration of the root mass close to the soil surface becomes more and more pronounced and is accompanied by a reduction in root weight. In park and sportfield lawns kept short, only a very shallow soil layer is rooted through. Deep rooting is not at all important for a grass sward with sufficient water and nutrient supply. The ease of transplanting thin pieces of a turf without great interruption of the growth is proof of that. In this way some good pasture sward with a minimum of soil was transported over hundreds of miles for the establishment of sport lawns. The most important selection factor in mowed swards is the frequency of cutting combined with the time of cutting. Both are effective through the spe- cific time requirement for reserve storage of each species. Mowing meets all plants at the same time and leaves a stubble poor in chlorophyll and not able to assimilate. This is the most substantial difference between pasture use and cutting. It is not the contrast between the cut and the bite of the grazing animal that earlier was thought to be decisive. Frequent cutting in a park lawn may have effects similar to intensive grazing so far as a sufficient assimilating leaf area being left is concerned.

\section{Behavior of the Grass Sward Under Grazing}

This is closely correlated with the behavior of the grazing animal (Klapp, 1954; Voisin, 1953; 1957; Wehsarg 1935). Grassland research and no less the breeding and testing of pasture plants should not overlook this fact. In utilization by grazing the storage requirement of the plant is affected both by the taste, and by the kind of bite and trampling of the grazing animals. The requirements of the plant do by no means coincide with those of the uncontrolled animal. That alone makes understandable the particularly heavy selection of the grazing animal. The greatly different effects of the animal on plant species and the local variation of floristic composition and productivity of the grass sward give great variability to the total grazing effect. But some basic facts are always maintained. Simply stated the grazing animal eats what it likes and disdains what it does not like. That means protection and strengthening for the disdained plant insofar as it is not hurt by trampling.

What does the grazing animal like? This question is not less difficult to answer than is the question of the taste of men. Attempts have been made to answer it by grazing experiments on fields with pure stands of various grasses and other forage plants. The results correspond very little to the behavior of the animals on common pastures and are partly misleading. In such experiments the time that grazing begins decides the "palatability range" of the tested species and varieties. The first quick growth is always preferred. Early growing and therefore important species are disdained by a late start of grazing and so on.
Otherwise under common pasture conditions less palatable species are grazed too, if they grow in a mixture, for instance, with white clover. Relatively few species are willingly grazed or otherwise disdained under all conditions. The rank of palatability of the species will change with the season, the time of day weather conditions, the accompanying flora, the water and nutrient conditions of the soil. Breed and individuality of the grazing animal may cause principal differences of their taste. Age, level of fill, conditions of the animals, and other things affect it further. Animals observe an individually differing menu, if various crops are accessible, indicating that the palatability of plants is not certain. British experiments (Ivins, 1952; Jones, 1952; Milton, 1953; Reid, 1951) are particularly informative. The results of retort and microscop, e.g., anatomical-morphological characters, give only little evidence in this respect for the evaluation of varieties. Only long-term observations of a large number of animals under changing conditions give reliable results (Bohne, 1955).

We will discuss only briefly the grazing effect of the single animal species by their bite and trampling and by the kind and deposition of their excreta (Johnston-Wallace, 1950; Klapp, 1954; Wehsarg, 1935). Grazing by cattle, avoiding serious mistakes, easily develops and maintains satisfactory pasture swards. The grazing hog may develop very good pasture swards, if it is curled or otherwise prevented from rooting. Horses, sheep, and geese are particularly detrimental as the only animals on permanent pastures. If they graze as a minority together with cattle the total effect may be favorable.

With uncontrolled grazing the preference of palatable plants leads to their overuse so far as an equilibrium is lacking between forage production and forage needs of the grazing animals. Good growing conditions and a low stocking rate allow sufficient possibilities to store reserve material even for the preferred species. But with low productivity and heavy stocking the preferred species are grazed so often and so heavily that the storage of reserves is insufficient and their vitality is weakened to the death of the plants. 
Very ample forage growth of a pasture is by no means favorablc for the maintenance of a good and even sward with uncontrolled grazing. The pasture is not equally grazed and a part of the forage becomes superseded particularly in places by rank growth. These are the starting points of "weedyness" with disdained species. The animals have enough forage, space and possibilities to move around to keep off the places of the ample growth. The same is true for any plant growing outside the dung places; it may be poisonous, thorny, woody or heavy smelling. Thistles in our area, thornbushes in other countries are the sign of underuse.

As mentioned before, low forage productivity of the pastures or continuous over stocking leads in the long run to exhaustion and disappearance of the preferred species. Those species which are never touched are spared, e.g. dwarf shrubs, juniper and such plants not reached by the bite of the grazing animal, and those, such as rosette plants which are resistant against trampling ( $v$. Bothmer, 1953). But finally these plants do not persist, bare soil increases and the overuse becomes a dangerous cause of erosion.

There are no sharp boundaries between under- and overuse. Both may be observed side by side. So we find large patches of spared weeds mostly on horse pastures (since there is no force to search all over and trample them down), but beside them always preferred and overgrazed places.

At the extreme, both forms of grazing mistakes may be easily recognized; the thistle hordes of undergrazed fattening pastures on the one hand; juniper, heaths and matgrass (Nardus stricta) ranges on the other hand.

But the great possibilitics of combinations of sites, flora, kinds of grazing animals and grazing systems correspond to a similar large range of selection effects. In some overseas countries cattle grazing leads to an unrestrained increase of blackberry (Rubus fruticosus) bushes, but goat grazing to their disappearance (Klapp, 1956).

The basic principle remains always the same; weakening or at best maintenance of the palatable plants and sparing, i.e. strengthen- ing of the disdained and ungrazed plants.

This process is so enduring that it determines the physiognomy of the landscape and may remodel it by a change of the animal husbandry. Today's appearance of the Scottish highlands (Fenton, 1951/52) but also of many high mountain pastures (Kerner, 1941) reflects the qualitative and quantitative changes in the animal husbandry of the 19th and 20th centuries.

Whatever the grazing animal disdains becomes a weed for the grassland farmer or rancher. Woody plants of various kinds from juniper to broom, hard grasses, thistles and restharrow, rough bushes and poisonous plants even supersede forage plants of the dung patches. Their detrimental effect becomes of indirect and particular importance by the shelter offered to various insect pests and parasites. The decisive importance of bad pasture management for the origin of pest calamities was recently impressively shown (Richter, 1952; 1955). Rosette plants which escape the bite become weeds too. Otherwise the grazing animal cleans up the grass sward of numerous species which are weeds under meadow use. But the grazing animal makes some meadow weeds into valuable pasture plants, because it likes them and eventually their disadvantages for hay curing become meaningless on the pasture. Fortunately the scythe and the cutter bar select differently or even opposite from bite and trampling. Only many cuts and overgrazing approach one another in the selective effect by promoting plants close to the ground, which escape both cut and bite.

\section{Defects in Soil Structure}

Finally disadvantageous effects in selection start from defects in soil structure. These may originate in the natural soil and water conditions, in weather extremes or in management mistakes. A conspicuous example is the invasion by rushes (Juncus sp.) on hard pan soils (Gaedeke, 1941; Reincke, 1933). It may be originated by the natural tendency of a soil for compactness (pseudo-gley, very decomposed bog soil). But here and on soils without the tendency to compaction it is usually the consequence of rolling, grazing and driving over at the wrong time. Rushes grow much better with reduced air and increased water content of the soil than the desirable forage plants. Trying to loosen compact grassland soils with cutting or ripping equipments will produce only an increase of annual weeds (Klapp, 1932) beside a direct damage of the sward as a rule. Like the effect of a hoe in grass seed production fields grown together, rending of the grass sward leads to heavier flowering and seed set only of the grasses. Additionally there is made a seedbed for seeds of all kind. The loosening of too compact grassland soils needs methods suited to the grassland.

Excessive looseness and aeration are found predominantly on soils rich in humus, mostly less decomposed bogs. Generally the soil of a hay meadow is more loose than the soil of a heavily-used pasture. Apart from the natural tendency of some soils to self-loosening, heavy frosts may cause undesirable loosening. The unusual enlargement of soil porosity, i.e. essentially of the overcapillary pores, involves more aeration and even heavier nitrification in humus soils. The result is a quick spread of plants which prefer a loose soil (also in respect to an uninterrupted rhizome development) or are favored by abundant nitrogen; stinging nettles (Urtica dioica), meadow bedstraw (Galium mollugo), Umbelliferae, also yarrow and meadow knotweed (Polygonum bistorta). On large areas, particularly well drained bogs, these weeds of the loose soil are a serious danger for new seedings on a plowed old sward. So again compaction and loosening produce specific selection effects. We should use them diagnostically and learn the possible counter-effects.

\section{New Seedings}

Changes of the greatest degree accompany any new seeding left to itself (Klapp, 1954; Stapledon and Davies, 1928). They compare with the quick change in clear-cut forests left to natural succession. In both cases the removal of the old plant cover causes increased decomposition of the soil. In plowed grassland soil loosening is even more effective. The more rapidly growing species there are in the seed mixture the more the developing stand resembles a pioneer vegetation. At first the quick-growing species dom- 
inate the field. They occupy the air and root space to the disadvantage of the slow and short growing species. If there are shortlived species like red clover (Trifolium pratense) or Italian ryegrass in the mixture their disappearance in the second winter leaves large bare spaces. Native species, both valuable and worthless, invade. The breakdown of the pioneer stage is delayed with longer-lived species. Yet the greater use, particularly of perennial ryegrass, often results in a disastrous formation of blanks and weedyness on unsuitable locations. One unusually hard winter will cause such changes in perennial ryegrass. But even a well-adapted mixture according to existing opinion, is not exempt from large changes, the development of blanks, and the invasion by native flora. The severity of competition may be recognized from the fact that often only five to ten percent of the plants present the first year are found in the third or fourth year after seeding (Volkart, 1933). All the rest succumb to competition. This fate hits even robust species, which at first might have competed well. At first this is surprising but we must not forget that the plowed soil also goes through great changes (Klapp, 1954). In the fresh, loose, plowed soil large amounts of organic substances, stubbles and roots, and the soil fauna which die with the plowing (Franz, 1950) are quickly decomposed. The quick and tall growing species of the seed mixture may draw on plentiful resources. They pillage the nutrient and water resources of the soil to the disadvantage of the slower growing species. The waste of humus and the impoverishment of the edaphon lead to soil compaction. The ample first growth diminishes more so the quick-grown pioneers finish their life cycle earlier than in an already closed grass sward. The slow growing species have more space with the reduction or even disappearance of the fast growing ones. But there is left only a compact soil, deteriorated in nutrients and those species are not able to compete aggressively with the invading native species, the seeds of which are practically ubiquitous. Only gradually the process goes through these "years of hunger" with increasing formation of humus and edaphon to a new friable state of the grassland soil (Grünlandgare) and to a well adapted plant community i.e. to an equilibrium with the environment.

We have spoken here explicitly of new seedings "left to themselves." The more we learn about the aftereffects of plowing on the soil and the community metabolism the more we may open possibilities of counteracting especially to reduce the murderous competition and the deterioration of the soil. These facts are characteristic of the "years of hunger" and are not entirely mistakes in soil preparation, fertilization and mixture composition of the reseeding.

\section{Conclusions}

We have shown the reaction of the grass sward to changes in the environment and management by a number of examples. But the possibilities are much more manifold without establishing an essential change of the basic principles. These basic principles may be the framework of a general grassland theory, i.e. of the counterpart to the general cropping theory. Let us recall once more the differences. The raw material of cropping is the soil, its cardinal aim to create the best growth conditions in the form of a friable soil. The tools of cropping are soil preparation, fertilization and cultivation (including weed control). All serve the single plant species in a pure stand, at least with cash crops, and even the single plant with widely-spaced crops.

The raw material of grassland management is the grass sward; its cardinal aim to create a productive plant community. Its tools are fertilization, mowing, and grazing. The importance of the soil is very much reduced. Soil preparation is an exception, since the current renovation of the friable state of the soil is not necessary. The object of the work is not the single plant and the single plant species but the side-by-side and joint existence of a large number of species varying from site to site.

Particularly, fertilization is common to both forms of plant production, although its application and effect show large differences in both cases. Also, weed control at least in its aim, is common to both forms. In cropping it is a special measure and in the grass sward it corre- sponds to a large extent with management procedures, i.e. "harvesting technics" and fertilization, leaving out chemical weed control. On the other hand harrowing and hoeing as control procedures are not applicable.

Above all we have to realize that the annual cash crops of arable fields do not need consideration for regeneration, regrowth and hibernation while the grass sward always needs this consideration. Perennial forage crops and field crops such as beets and potatoes for seed production have something in common with the grass sward in this respect.

The most important character of the mixed plant community for grassland management is its plasticity, i.e. the unstable equilibrium between numerous competitors. The competition pressures of the different species are only temporarily compensated with stable environmental conditions. Any influence, or interference from outside, shifts the relation of the forces, has selective effects, favors some species, and is detrimental to others. Fertilization effects on storage and exhaustion of reserve material and on plant regeneration are especially effective. Here, I suppose is the most important point for the treatment of the grass sward. It is necessary to direct competition and selection in such a way that the desirable plants, but not the undesirable ones, get the opportunity for sufficient regeneration.

Considering all influences, those effecting storage as well as the less decisive ones, the aim is to increase the competitive ability of all species most valuable for the intended purpose. The purpose, for instance grazing, may require reduction in the competitive ability of high-class meadow plants when they are unimportant for grazing.

Important plant characteristics in the competition are rate and ultimate height of growth. Each rapid and tall-growing species competes strongly with its neighbors, first by inhibition of the assimilation process, through shading and also by horizontal expansion. Tall-grass meadows typically show much bare soil as a result of shading. The reaction of various species to specific fertilizer treatments is similarly important. The increased competitive ability of some tall grasses by ap- 
plications of $\mathrm{N}-$, of climbing legumes by $\mathrm{K}_{2} \mathrm{O}-\mathrm{P}_{2} \mathrm{O}_{5}$ - and of some Umbelliferae by one-sided liquid manure fertilization are typical examples. Species peculiarities of regeneration, rooting, bunch and rhizomatous growth and other characters further determine competitive ability. Some species with a low light requirement such as roughstalked meadow grass are able to compete even against tall-growing species if other conditions are favorable. The competitive ability of a spccies is of course not absolute but largely dependent upon habitat, species composition, and management. If height growth of a species is continuously kept short, it loses a great deal of its superiority. In this way it is understandable that grazing creates another or even opposite rank of the competitive ability than hay cutting. Likewise the kind of fertilization involves shifting of the mutual competitive ability. So fertilization, mowing and grazing offer very differently directed aids to govern competition, which is the foundation of sward management. But in the case of very wet meadows the impossibility of grazing prevents full control. In countries adjusted only to grazing, the ungrazable wet meadow is little more than waste land.

Herbs may increase greatly in exclusive meadows for various reasons so that grasses and legumes are almost completely absent. In other cases poor grasses dominate. Fertilization is the most important tool for improvement. In many but not all cases it may drive back the undesirable species, particularly those typical of poor grassland, by encouragement of their more pretentious competitors. Fortunately the majority of the high value forage plants are likewise pretentious. So, the poor meadow is the most profitable object for fertilization but the one-sided, overfertilized meadow the most unprofitable one. Occasional successes may be obtained with the correct use of the roller on suitable soils. There are very few possibilities of using only utilization as the most effective measure for the life of the grass sward. We have seen that changes in time and frequency of mowing are very limited. But the fact is too little known that an effective close cut is very bad for some bunch grasses, e.g., tufted hairgrass (Deschampsia caespitosa). In these species the regular disturbance of the tillering zone leads at least to a large reduction. In humid areas with greatly subdivided land properties, frequent mowing of the heavy fertilized green forage meadows is an aid in that the dominant herbs are always used as forage in the young, high value growth stage. Its limited economic possibilities of nitrogen application are the weakest point of the exclusive meadow, at least in the average clover-rich meadow. High rates of nitrogen here bring the most vigorous tall grasses to dominate at the expense of the legumes and thus extend the uniformity of the plant community. Apart from the reduction of the forage value there is developed in this way a pretentious and labile plant community dependent on continuous heavy fertilization and with unstable productivity. This one-sided selection may be at best countered by laborious frequent mowing. But again this causes new unfavorable selection effects. One proven way out is alternating fertilization (Klapp, 1954; Zürn, 1951) insofar as it succeeds in sufficient recovery of the short grasses and legumes in the years without nitrogen application. Altogether the exclusive meadow offers too few possibilities of directing competition and plant selection. Therefore the most important aim is sufficient drainage where conditions are too wet and consolidation where subdivisions of agricultural units exclude grazing use.

Almost unlimited and so far hardly exploited possibilities to direct the grass sward are otherwise offered on all grassland, which allows at least temporary intensive pasturing. Of course it has to be grazed during times of active growth. Grazing of the regrowth in late fall is only slightly selective, because most species have completed their reserve storage at this time and are hurt very little. We speak here of grasslands which are grazable at least during some month of the summer or the whole year round. Let us think of an average meadow with its typically bad characteristics: high proportion of inferior, seed-shattering, early-flowering species; big, slow-storing, tall bushes, species often injurious to animal health; few short grasses and legumes with high nitrogen application; and an open grass sward poor in lower leaves.

A herd brought in at a stage of advanced plant development will graze very selectively. It will graze all of the young palatable green growth first but disdain the early matured and already strawy material and all the less palatable plants. Some will be trampled down and much will remain untouched. At this stage nothing seems improved. However the "modeling out" of the disdained plants now makes possible their aftermowing and removal irrespective of the best time for cutting the meadow. The repetition of this procedure means that trampling and mowing shorten the storage time below the amount necessary for almost all tall bushes and thus prevent seed ripening, disturb the bunch grasses and increase density of the grass sward. The removal of the shading permits an increase in the short grasses as well as the low legumes. Some few tall grasses are somewhat hurt, but they recover soon with temporary meadow grazing since they are less sensitive than most bushes. Selection by grazing is thus supplemented by mowing. That is the foundation of the good grass swards on farms with hay pastures. Insofar as weed control is important, it is decisive always to graze during the time of most vigorous growth of the undesirable species, i.e. before the heaviest reserve storage takes place. This means grazing from the earliest possible date when early growing and first-cut meadow species are vigorous and again after the start of regrowth of weeds common in the second cut.

Weedyness and any misdevelopment of a permanent grass sward are caused by selective grazing and trampling. The mistake may be over- or undergrazing. In every case the valuable, palatable plants are overused in some places or on the whole pasture and the undesirable plants spared for undisturbed reproduction. Not shading, but interruption of storage and regenerative ability, weakens the competitive ability of the valuable plants. For more than 250 years it has been known that this phenomenon may be easily avoided by interrupting 
grazing use with regular rest periods. Before paddock divisions and the electric fence became common, the tethering stick was the ideal solution. It was ideal insofar as the grazing animal was forced to graze and trample entirely in the tethering circle and this in a short time followed by an adequate rest period for grasses and clovers. The principle, "short grazing times, long rest periods," has no other aim than to keep down troublesome competitors with long storage times and to favor the well adapted pasture plants with short storage times. This aim may be practically reached everywhere, when we obtain a balance between the productivity of the grass sward and the feed requirements of the grazing animal. Then the surprising fact results not only of a qualitive improvement of the grass sward but also of an essential increase in the productivity without additional fertilization.

It is not possible to eliminate entirely the selective effect of grazing. At least the grass in the dung places is avoided temporarily and they become unresistingly seats of weeds and insect pests. Here again we should use mowing.

Finally there is one particular advantage of grazing. The inevitable disadvantages of a corresponding meadow fertilization do not occur. These are predominantly caused by the shading effect of the tall growing grasses and herbs. Grazing so restricts their competitive ability that light-hungry short grasses and white clover do not need to give way even under the heaviest $\mathrm{N}$-fertilization.

Even with a grazing system at first thought to be appropriate, unfavorable selection effects may appear, if the grass sward produces less than the grazing animal requires, i.e. in the case of repeated overuse. Weakening of the good pasture plants up to annihilation, permits then a whole range of light and space requiring species which are not grazed, and grow undisturbed. Here it is necessary to increase the competitive ability and particularly the shading effect of the desirable plants by the reverse of the principle of meadow grazing. The exhausted pasture sward is given time to grow tall together with plenty of fertilization and is mowed each time in an advanced stage of growth up to visible success, i.e., the disappearance of soil-attached rosettes and light weeds and a sufficient strengthening of the good pasture plants. The old saying, "the scythe is the enemy of the pasture", is only valid when tall growth is permitted regularly or when it is continued a long time after its purpose is attained. The contrary is regular early and long applied meadow grazing particularly by sheep. While repeated mowing of pasture leads gradually to a sward similar to meadow, so the repeated grazing of meadow in early summer leads to a sward similar to a pasture, which may be an advantage.

It may perhaps be striking that we speak so much of weed control. In fact grassland improvement and grassland management are identical with the displacing of those plants commonly called "weeds". But it is much more difficult to describe precisely the term weed in the grassland than in the arable field. Of course, the custom of calling all grassland plants, except grasses and clovers, weeds which have to be controlled, seems fortunately to have come to an end (Boas, 1953; v. Grünigen, 1949; Klapp, 1954). We know that many forbs are superior to the grasses in protein and even more in mineral content including minor elements (Ahrens, 1957; Bender, 1940; v. Grünigen, 1949). Likewise some forbs rank far ahead in palatability. Observation of the grazing animal shows that it occasionally prefers "weeds". Otherwise even valuable plants may develop weed characters if they dominate too much, become too old or make the harvest difficult. Our weed term (Klapp, 1954) is determined by the desire to consider this variability of the weed character. It includes "all species which are deterimental, directly or by their dominance, to the animal, to the grass sward or to the economy of grassland utilization".

There are only few weeds in this sense, which may not be displaced or restricted to an unimportant level, the behavior of which corresponds largely to that of the desirable plants. When one is not able or willing to use the necessary management procedures, then chemical weed control remains as an alterna- tive (Rademacher, 1953). In spite of all biological and technical differences, it has in common the selective effect of management procedures. It relieves the undamaged plants of competition. This relief becomes more effective as the competitive ability of the remainder is promoted by fertilization and encouragement of reserve storage.

Thus all procedures for maintenance and improvement of a good grass sward may be reduced to some few basic principles more readily than for crops. Perenniality and association of the grassland give leading consideration to the rhythm of storage and exhaustion on one hand and to competitive behavior of the species on the other. The art of sward management consists of the promotion of competitive ability of desirable plants by weakening and exhaustion of their undesirable competitors. Suppose a suitable habitat, appropriate fertilization, controlled grazing, and mowing are the main management tools. Each has to provide the desired equilibrium between the productivity and the exploitation of the grass sward. It is a fortunate concurrence then that our procedures effect favorably both the quality and the quantity of grassland production.

\section{Summary}

For an unbiased consideration of permanent grassland in research and teaching, clear understanding of the differences between cropping and grassland management is necessary. The raw material of cropping is the soil; its tool, soil preparation in the widest meaning; its aim, the uninterrupted growth of the single plant species. The raw material of grassland management is the grass sward, making unnecessary any soil preparation. The most important tool is the kind of utilization; its aim, the development of a productive plant community. Common features for both kinds of land use are found particularly in fertilization.

The decisive character of the grass sward as a species association does not diminish the importance of the single species. Its 
behavior as a single crop without the competition of other species admits nothing or only uncertain conclusions concerning its behavior in the dense grass sward. The difficulty and the length of experiments with mixed seedings make vegetation ecology indispensable.

The main point of influence of the grassland treatment is the competitive ability of the species. Within the plant association at any one site, a labile equilibrium of competitive abilities develops under homogeneous conditions. Any change of the environmental conditions including those affected by man and animal may shift this equilibrium at least in the mass proportion. The increase of the competitive ability of one species means mostly a reduction of another.

Among management procedures, changes in fertilization may effect considerable changes in the competitive ability. Influences of the kind of utilization upon the regeneration of plants, particularly upon the storage of reserve material, are still more effective. Grazing and mowing as management procedures moreover have a more or less controversial effect. This is similarly true for fertilization. That opens the possibility of equalizing undesirable consequences of one management procedure with the application of another.

Any change of the environment of biotic or abiotic nature earlier or later affects selection in the plant community. Working method and aim of the sward treatment affect the direction of selection in such way, that the competitive ability of the desirable species is increased and that of the undesirable ones is decreased. The possibilities are greater on sites which permit the use of mowing and grazing at any time. On the hay pasture all improvement and management procedures are largely identical with utilization procedures, i.e. with harvesting techniques. Special procedures which are the rule in cropping become indispensable only if grazing is impossible.

In total a grassland theory may subsist upon very few working hypotheses and theories. Its foundation is the behavior of the grassland plants within the species association.

\section{LITERATURE CITED}

Ahrens, E. 1957. U̇ber den Spurenelementgehalt einiger Grünlandpflanzen und des Heues bei verschiedener Wiesenbehandlung. Diss. Bonn.

Baur, G. 1930. Das Grünland in Lehre und Forschung. Hohenheim.

Bender, H. 1940. Der Nährstoffertrag des Dauergrünlandes. Berlin.

BoAs, F. 1953. Unkraut oder biologisch unbekannte Pflanzen. $Z$. Pflbau u. Pflschutz 4.

BoHne, B. 1955. Ein Beitrag zur Feststellung des Geschmackswertes der Grünlandpflanzen. Grünland, iss. 4/5.

v. Bothmer, Graf, H. J. 1953. Der Einflu $\beta$ der Bewirtschaftung auf die Ausbildung der Pflanzengesellschaften niederrheinischer Dauerweiden. Z. Acker-u. Pflbau 96.

Braun-Blanquet, J. 1951. Pflanzensoziologie. 2nd Ed. Wien.

BrüNnER, F. 1956. Die "Fruchtfolge" im Grünlandbestand. Grünland 5 .

Caputa, J. 1948. Untersuchungen über die Entwicklung einiger Gras- und Kleearten in Reinsaat und in Mischung. Diss. Zürich.

Champness, St. S., AND R. Morris. 1948. The population of buried viable seeds in relation to contrasting pasture and soil types. J. Ecol. 36 .

Davies, W. 1948. Grassland as a biotic community. J. Brit. Grassland. Soc. 3.

Davies, W. 1948 a. Foggage. J. Min. Agric. 55.

EllenberG, H. 1952. Wiesen und Weiden und ihre standörtliche $\mathrm{Be}-$ wertung. Stuttgart-Hohenheim.

ElleNBERG, H. 1956. Grundlagen der Vegetationsgliederung. In WALTER, H. Einführung in die Phytologie. Part I, Vol. III, Stuttgart.

Fenton, E. W. 1951/52. The influence of man and animals on the vegetation of certain hill grazings I and II. Edinburgh and East of Scotland Coll. Agric., Tech. Bull. 4/5.

Foerster, E. 1956. Ein Beitrag zur Kenntnis der Selbstverjüngung von Dauerweiden. Z. Acker-u. Pflbau 100.

Franz, H. 1950. Bodenzoologie als Grundlage der Bodenpflege. Berlin.

GAEDEkE, F. 1941. Untersuchungen über einige physikalische Eigenschaften des Niederungsmoorbodens in Beziehung zum Pflanzen- bestand von Wiese und Weide. Ldw. Jb. 91.

v. Grünigen F. 1949. Die Bedeutung der Unkräuter für die Ernährung des Rindviehs. Proc. 5th Int. Grassld Congr.

Hughes, G. P. 1953. Grassland management for winter grazing. Agric. Progress, Vol. 28, Part 2.

IviNs, J. O. 1952. The relative palatability of herbage plants. J. Brit. Grassld Soc. 7.

JoNEs, L. J. 1952. Measurement of palatability. Proc. 6th Int. Grassld Congr.

JoHNSTON-W ALLACE, D. B. 1950. Grass and the grazing animal. Fmr's. Wkly. 11/12.

Jones, M. AND L. J. Jones. 1930. The effects of varying the periods of rest in rotational grazing. Welsh Pl. Breed. Sta., Ser. H, No. 11, Shrewsbury.

Kerner v. Marilaun, A. 1941. Die Alpenwirtschaft in Tirol. Osterr. Rev. 1868, reprint.

KLAPP, E. 1931. U̇ber den allgemeinen Düngungserfolg auf Wiesenland. Ernähr. Pfl. 27.

KLAPP, E. 1932. Über das Eggen, Ritzen (Verwunden), Walzen und Nachsäen auf Wiesen. Fortschr. Ldw. 7.

KLAPP, E. 1941/42. Entwicklung, Wurzelbildung und Stoffspeicherung von Futterpflanzen. Pflbau 18.

KLAPP, E. 1942/43. Über Bodenlockerung, Umbruch und Hungerjahre von Grünlandflächen. Pflbau 19.

KLAPP, E. 1944. Zur Ein- oder Unterbringung von Düngernährstoffen (Tiefendüngung) auf Dauergrünland. Z. Bodenkde. PflErnähr. 33.

KLAPP, E. 1949. Landwirtschaftliche Anwendungen der Pflanzensoziologie. Stuttgart.

KLAPP, E. 1954. Wiesen und Weiden. 2nd Ed. Berlin.

KLAPP, E. 1956. Futterbau und Futterwirtschaft in Chile. Bonner Geogr. Abhdlgn. 17.

KLApp, E. 1958. Leistung, Bewurzelung und Nachwuchs einer Grasnarbe unter verschieden häufiger Mahd und Beweidung. Z. Ackeru. Pflbau 93.

KLAPP, E. AND E, Schulze. 1957. Versuche über Stoffbildung und Stoffspeicherung bei mehrjährigen und mehrschnittigen Futterpflanzen. Z Acker - u. Pflbau 103. and $f$.

KLITSCI, U. 1932/33. Ein Beitrag zur Umbruchfrage des Grünlandes vom Standpunkt der Bodenphysik. Pflbau 9.

KNAPP, R. 1955. Experimentelle Soziologie der höheren Pflanzen. Ludwigsburg.

KöNEKAMP, A. AND F. KöNIG. 1929 Über den Einflu $\beta$ wirtschaftlicher Maßnahmen auf den Pflanzenbestand des Grünlandes. Ldw. Jb. 70.

KöNIG, F. 1950. Die Rolle der Nährstoffversorgung bei der Leistungssteigerung der Wiese. Ldw. Jb. Bayern 27.

KraUse, W. 1953. Ưber den Einflu $\beta$ winterlicher Bewässerung auf 
Bergwiesen des Schwarzwaldes. Z. Acker- u. Pflbau 97.

LenNarTz, H. 1957. Über die Beeinflussung der Keimfähigkeit der Samen von Grünlandpflanzen beim Durchgang durch den Verdauungstraktus des Rindes. Z. Acker-u. Pflbau 103.

LINKOLA, K. 1935. Über die Dauer und Jahresklassenverhältnisse des Jugendstadiums bei einigen Wiesenstauden. Acta Forest. Fenn. 42.

Milton, W. E. J. 1953. The palatability of herbage in undeveloped grasslands in West-central Wales. Emp. J. exp. Agric. 21.

MORGENWECK, G. 1941/42. Strukturvergleiche von Acker - und Grünland. Pflbau 18.

RADEMACHER, B. 1953. Das Verhalten der wichtigsten Grünlandpflanzen gegen herbizide Wuchsstoffe. Z . Acker-u. Pflbau 97.

REID. D. 1951. A. quantitative method for determining palatability of pasture plants. J. Brit. Grassld Soc. 6.

REINCKE, R. 1933. Die Binsen, ihr Vorkommen und ihre Bekämpfung. Dtsch. Ldw. Presse 60.

REMY, TH. AND J. VAsTeRs. 1931. Untersuchungen über die Wirkung steigender Stickstoffgaben auf Rein- und Mischbestände von Wiesen- und Weidepflanzen. Ldw. Jb. 73.

RICHTER, W. 1952. Erfahrungen mit wuchsstoffhaltigen Mitteln bei Unkrautbekämpfungsversuchen auf. Weiden. Grünland 1.

RICHTER, W. 1955. Pflanzensoziologische Untersuchungen zur Okologie von Grünlandschädlingen. $\mathrm{Z}$. Acker- u. Pflbau 99.

Schmithüsen, J. 1942. Vegetationsforschung und ökologische Standortslehre. Berlin.
SchünemanN, W. 1933. Experimentaluntersuchungen über die $\mathrm{Ge}-$ staltung der physikalischen Bodenkonstanten unter verschiedenen Formen natürlicher und neu angelegter Grasländereien. Z. Pfl. Ernähr. Düng. A 32.

SchUlze, E. 1954. Zusammenchänge zwischen Düngungserfolg, Pflanzenbestand und Schnitthäufigkeit auf Dauerwiesen. Grünland 3.

Schwarz, R. 1933. Über den auswählenden Einflu $\beta$ verschieden hohen Grundwassers auf den Pflanzenbestand einer Rohrglanzgraswiese. Kulturtech. 36.

Smelow, S. P. 1937. Theoretical aspects of grassland farming. Herb. Rev. 5 .

Stapledon, R. G. and W. M. Davies. 1928. Seed mixture problems, competition. Shrewsbury.

StEBLER, F. G. AND C. SCHRöTER. 1887 a. Über den Einflu $\beta$ des Bewässerns auf die Zusammensetzung der Grasnarbe der Wiesen. Ldw. Jb. Schweiz 1.

Stebler, F. G. AND C. Schröter. 1887 b. Einflu $\beta$ des Beweidens auf die Zusammensetzung des Rasens. Ldw. Jb. Schweiz 1.

STEBLER, F. G. AND C. Schröter. 1887 c. Untersuchungen über den Einflu $\beta$ der Düngung auf die Zusammensetzung der Grasnarbe. Ldw. Jb. Schweiz 1.

STEBLER, F. G. AND C. Schröter. 1892. Versuch einer Übersicht über die Wiesentypen der Schweiz. Ldw. $\mathrm{Jb}$. Schweiz 6.

Stebler, F. G. and A. Volkart (L. ScHRöTER) 1898. Die besten Futterpflanzen. Vol. 4, Die Streupflanzen. Bern.

Troughton, A. 1957. The underground organs of herbage grasses.
Commonw. Bur. Past. and Field Crops. Bull. 14, Farnham Royals, Bucks.

Tüxen, R. 1939. Die Pflanzendecke Nordwestdeutschlands in ihren Bezichungen zu Klima, Gesteinen, Boden and Mensch. Dtsch. Geogr. Bttr. 42.

VoHL, F. 1935. Über das Verhalten verschiedener Pflanzenarten in Grünland-Saatmischungen. Diss. Hohenheim.

VoIsIN, A. 1953. Comment la vache s' alimente elle-meme au paturage. Rev. Elevage 8.

VoIsin, A. 1957. Productivité de l'herbe. Paris.

VolKART, A. 1933. Wie stellt man eine Kleegrasmischung zusammen? Schw. Bauer.

De VRIES, D. M. 1940. Over den invloed van strenge koude op de graszode. Landbouwk. Tijdschr. 52.

DE VRIes, D. M. 1942. Over den invloed van jaargetijde en weer op de botanische samenstelling van grassland. Nederl. Kruitkund. Arch. 52.

DE VRIES, D. M. 1943. Over de ongeslachtelijke vootplanting van grassen in de weide. Landbouwk. Tijdschr. 52.

WEBER, C. A. 1929. Ausläufertreibendes Deutsches Weidelgras. Mitt. D.L.G. (St. 41).

WEBER, C. A. AND A. EMMERLING. 1917. Beiträge zur Kenntnis der Dauerweiden in den Marschen Norddeutschlands. Arb. D.L.G. 61, Berlin.

WEHSARG, O. 1935. Wiesenunkräuter. Berlin.

ZüRN, F. 1951. Düngungswechse1versuche auf Dauerwiesen. Z. Pflbau, Pflschutz 2. 